\title{
The Indo-US Entente
}

\author{
Khalil-ur-Rehman \\ SZABIST \\ Karachi, Pakistan.
}

\begin{abstract}
In the east is Pakistan's traditional adversary India, an aspiring Asian power of the $21^{\text {st }}$ century. Across the Karakurams is an ancient practitioner of balance of power politics. To the west is occupied Afghanistan. From the south via Arabian Sea and Indian Ocean, oil and maritime world trade proceed, closely watched by American Navy. Indian blue water navy is a challenge. Further, deep south is US naval battle group at Diego Garcia. The locale echoes with major worldviews. Economies of national security are at play. Each has been involved in a power struggle. Asia is up for grab. Pakistan is stuck amidst the global and aspiring Asian powers. In this age and time, restraint is critical and an understanding of the passage of time is key. Time is however on the Indian side. The success lies in operating in continuum. Strictly speaking, in the context of nation-state system, nuclear weapon capability is Pakistan's threshold of tolerance. On an altitude of consciousness, all the governments since the last three decades fell prey to opposite threshold while guarding and developing Pakistan's nuclear weapon capability and delivery systems. Beyond doubt, it was played out in different ways.
\end{abstract}

Keywords: Foreign policy, Cognitive dissonance, Geopolitics, Baluchistan.

\section{INTRODUCTION}

Foreign policy's critical core is nation-state and national interest rooted in geography. The chemistry of Westphalian system is not in harmony with intangibles. Political identity and action is thus seen to be (more or less) determined by geography [1], in contrast to the one that remains oblivious to it. Transcendentalism of any kind disorients foreign policy. It is cognitive dissonance. Foreign policy can not be driven by ideas. The vital national interests, that is, geographical integrity, can not be pinioned with passions stemming from ideas like panIslamism. In Raj Naiti, dissonance driven perception becomes an agony once it seeks but in vain. The pursuits of nation-state revolve around security interests, power and wealth. Interests are defined and redefined, but identity and interests are not to be mixed. Diplomacy surrounding foreign policy manages tangible thresholds vital to national security. Foreign policy decisions involve political and geo-political judgements. Judgement is an abstraction part of policy involving mind and thought. And everything starts with thought and language.

An angle of diplomacy is synthesized and sustained brinkmanship. Pakistan has to steer a course between nationstate and its own cognitive dissonance. Foreign policy is competitive. The nature of competition is Manichaean,
Machiavellian, Clausewitzian, neo-Clausewitzian and Nuclear. An equalizer deters an aggressor. Nevertheless, an aggressive foreign policy is not in harmony with the nuclear logic, since it can lower the threshold. Deterrence can breakdown. The choice will be survival or obliteration. Is limited war feasible from an Indian perspective?

Despite the tragedy of October 8, 2005 earthquake, there is a lack of reason and compromise and an absence of magnanimity. It is a counsel of despair. Will wisdom and temperance prevail to conclude peace and spare resources for broader needs? Let it be a co-operative effort, not an Orwellian. Other than pretensions, trends are contradictory. Reality indicates the things to come. The split is unbridgeable and mistrusts deep. Ambition and sickness are customary; the very catalysts of arms race. Aphrodisiac of power intoxicates. All are talking at each other, but not with each other. It is unedifying.

Crisis in Kashmir, the Middle East or the Korean Peninsula affect security in every continent and are the concerns of everybody [2]. In the past the balance of power relied on occasional wars to rebalance the system or to deter aggressors but in a nuclear age that is no longer acceptable and a minnow can still inflict unacceptable damage on a great power [2]. To avoid this in South Asia, nuclear castration of Pakistan is sought for. Bluff is tempting and provocative owing to twist and spin. Will an Indo-US skipping of the nuclear premise work?

Ronald Reagan, George H.W. Bush, Bill Clinton and George W. Bush all repeatedly ignored dissents (and domestic political difficulties) of allies, rejected compromise with adversaries, negotiated insincerely, changed the rules, rocked the boat, moved the goal posts and even planned inadequately to deal with the consequences if their policies went wrong [3].

The wars in Afghanistan and Iraq, treating Syria as a "low hanging fruit" or the earmarked nuclear castration of North Korea, Iran and Pakistan manifests an Indo-US entente to encircle China. These nuclear cards need to be struck down in order to achieve that. NATO's deployment in Pakistan after October 8 earthquake is interesting. Its presence is meant to buttress the dictator and not Pakistan. It is a curious situation. Russian and Chinese presence in the quake-hit areas represents Shanghai Cooperation Organization (SCO). Pakistan's Prime Minister attended SCO meeting held at Moscow within two weeks of October 8 earthquake.

In the greater scheme of things, the Indo-US entente has Eurasia in view as a sphere of influence. It is multi-layered. 
Despite a history of love-hate relationship, the two have finally met and found each other. An important aspect of this entente is the avoidance of nuclear war between India and Pakistan. In American perception, ensuring security against nuclear war in South Asia is linked with the nuclear castration of Pakistan. The internal situation in Pakistan made it easier for Indians to exploit American fears. The United States and India want to resolve this problem once and for all. As opposed to "allowing possession and not sovereign use", nuclear castration of Pakistan is now central to Eurasian chessboard. The Non-Proliferation Treaty (NPT) has been by-passed by the events. This paper elucidates South Asian geo-political reality, the Indo-US entente and Pakistan's foreign policy options.

\section{SOUTH ASIAN GEO-POLITICAL REALITY: ANALYSIS AND OPTIONS}

It is so difficult to choose a person whom one is not comfortable to put up with. The Indo-Pak relation is an example. It requires transcendence. It is part of language and consciousness. Two generations are witness to it and the third one is growing with it. Both need to be at peace with themselves first and then with each other. The graph in Figure 1 below represents an analogy of the current situation.

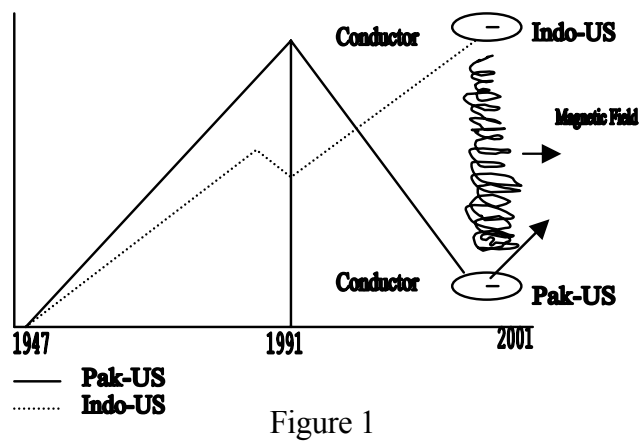

The graphic lines starting from 1947 are reflective of PakUS relations on the one hand and Indo-US relations on the other. The trajectory of the Pak-US relationship throughout the Cold War was on the rise. It reached its high mark in 1991. From then on, it nose-dived and hit the rock bottom by the year 2001. This was reflected in the four demands made by America on Pakistan before September 11, 2001: signing of the CTBT, prosecution of Osama bin Laden, co-operation against terrorism and withdrawal of support to the insurgent operations in the Indian occupied Kashmir. Then 9/11 occurred and Pakistan took a U-turn.

On the other hand, the trajectory of Indo-US relationship during the Cold War remained at low ebb. It shot up in the post-Cold War era and continues to ascend. The high point of this entente was Clinton's visit to India, resulting in multidimensional economic, strategic, cultural and geo-political co-operation. The manifestation of this new relationship is the document "Vision 2000" signed by the two countries during the visit. By the end of 2005, the Indo-US cooperation includes missile defense, arms sales, defense production, nuclear-cum-defense agreement and high technology trade. The Indo-US entente is directed at dominating Eurasia. Contrary to this, the relationship between India and Pakistan has been as two negatively charged conductors experiencing strong and repulsive electromagnetic field of force. The two negatively charged conductors can only repel each other.

In the context of war on terror, Indo-Pak thaw is in line with American interests. The nature of expeditionary operations has compelled the United States to operate with new and different allies and partners such as Pakistan and India [4]. For Pakistan, it is a new phase both ideologically as well as militarily. The military operations in Pakistan's tribal belt are a major undertaking. India has initiated dialogue after receiving direct commitment over ending infiltration in Kashmir. Yet others and India interfere in Balochistan.

Pakistan's position in relation to the war on terror has declined. The impetus it had gained initially has subsided. The operational alliance and an entente aiming at Eurasia have different connotations. US Secretary of State Condoleeza Rice's first visit to Pakistan was with a predetermined mind. The use of force against Balochi tribesmen during her visit was more than a coincidence. Dr. Rice conveyed American concerns. She was not explicit on defense cooperation, was evasive on Kashmir, and did not commit on Baglihar and declined to comment on violation of Indus Water Treaty by India. She rather stressed bilateralism. The diplomacy reflects consciousness and perception behind US foreign policy.

Historically, American consciousness is a combination of Emersonian idealism and geo-political interests. Idealism is to Congress, whereas the White House asserts US national interests. The convergence of American idealism and interests with regard to India is foreboding. The co-operative US-Indian relationship is because of the geo-political objectives of India, which it is pursuing in a very hardheaded way, and are quite parallel to American interests [5], including Indian democracy.

Moreover, as the focus of American war on terror shifted from Afghanistan to Kashmir and Pakistan's tribal belt, Islamabad's problems with Washington resurfaced. In addition to military operations in Pakistan's tribal belt, Americans are bent upon turning the Line of Control (LoC) into an international border and nuclear castration of Pakistan. In Indian perception, Pakistan is the enemy and China the competitor and former Prime Minister Vajpayee's emphasis was "not on building peaceful relations with China and Pakistan (a favourite Nehruvian line) but on developing the best possible relations with them through diplomatic and military means" [6]. India dreams of great power status, has a boundary dispute with China, is irked by its missile technology transfers to Pakistan, and has lost out to Beijing in securing oilfields in Africa [7].

Extra regional interference as an integral part of Pakistan's foreign policy [8], is no more to Pakistan's advantage. The 
emerging worldorder at the dawn of $21^{\text {st }}$ century is to Pakistan's discredit. The international system has tilted in India's favor. It will be difficult in the unipolar system for Pakistan to exert positive influence to convince the United States or other G-7 powers to alter their positions on issues central to their world order agenda [9]. Here comes in Pakistan's nuclear weapon capability that India and America want to dismantle. A major step on the road to Eurasia.

The inroads by Americans after the independent developments of Nuclear Tests and Lahore Declaration are significant. South Asian high politics have a different face. It is to India's benefit. Pakistan is on the defensive. Its balancing act involves China and America. India is exploiting to its benefit than ever before. A new US-Indian anti-Chinese alliance seems very likely to undermine the current efforts by Beijing and Delhi to improve relations, and could end up fostering greater tensions between them, dragging Pakistan into their quarrels [10].

Additionally, Deosai plains at 14,000 feet in the Northern Areas of Pakistan attract American geo-political and strategic interests. A military base at Deosai will be a force multiplier. It will be a cockpit to the surrounding regions and beyond. An Indo-US entente pointing at Eurasia, the Indian hegemony in South Asia, Gwadar, Deosai, nuclear castration of Pakistan and the future of Pak-US and SinoPak equations are linked. The jury is out on the Asian balance. The Sino-Russian partnership is a balancing move.

During a three-day official visit to Pakistan in April 2005, Chinese Prime Minister Wen Jiabao held out a categorical assurance to Pakistan to defend its sovereignty, independence and territorial integrity [11]. The centre of gravity of world affairs is shifting from the Atlantic, where it was lodged for the past three centuries, to the Pacific [12]. The holding of 2005 Indo-US and Sino-Pak joint naval exercises in Arabian Sea throws light on emerging equations. In American perception, the test of China's intentions will be whether its growing capacity will be used to seek to exclude America from Asia or whether it will be part of co-operative effort [12]. The inverted triangles shown in Figure 2 below reflect on Pakistan's foreign policy options.
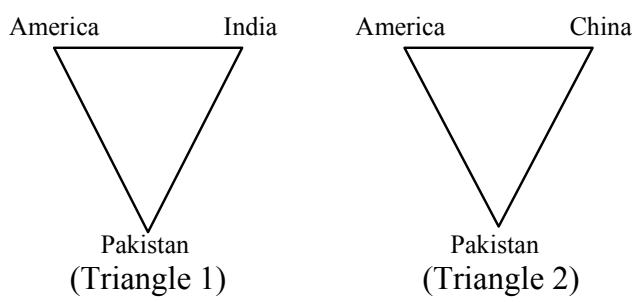

Figure 2

In case of an inverted triangle 1, Pakistan's foreign policy priorities should revolve around efforts, where Pakistan's relations with America will balance the rising trajectory of the Indo-US relations. Furthermore, with America and Pakistan at two ends, an inverted triangle each in case of
Palestine, Afghanistan, Iran, Iraq, Saudi Arabia, and Central Asian states synthesizes Pakistan's position. American goal is the Crescent of Oil within the Islamic Crescent. America envisages a role for Pakistan in the creation of an arc of moderate states.

Both empirically and interpretively, the truth is that an improved Pak-US relation will dilute the Sino-Pak equation in case of an inverted triangle 2. Compared to the past, it is different China and an altered Asia. If this is not so then what is the ado about? Pakistan has to forge a new relationship with China. At the moment, it is opaque.

\section{CONCLUSION/RECOMMENDATIONS}

As mentioned earlier, Pakistan is not located in a stable and safe zone, even seismologically. Obviously it can't relocate itself in space like an idea in mind. In international relations, this is the world of the calculus of interests and forces described by Machiavelli and Clausewitz and making peace is as much a part of sovereignty as making war [13]. Before we can begin to construct a foreign policy, we have to ask ourselves not only what sort of world we want to live in, but also who are we? [13]. A skeptic can afford to be a misfit and live the life of a recluse but not a country or a nation.

In the framework of Indo-US entente, India is the local policeman to tackle any situation in the region. In this context, the Indian perception had a measure of Pakistan; however, the news of the cruise missile test by Pakistan was received with sullen silence. It reaffirmed Pakistan's nuclear deterrence. Had it not been so, India would have pressed its advantage during Kargil. The equalizer works in the defensive posture. That's why the nuclear castration is intended to bring Pakistan naked to the negotiation table.

It has been noted in Pakistan and by analysts in Washington that despite the great interest America is said to have in improving Indo-Pak relations, this secured no mention in the joint statement after nuclear agreement nor was there even a hint that the status India sought internationally would be more easily endorsed if it was seen to be at peace with its neighbors in South Asia [14]. This is a new reality that must be factored into Pakistani calculation [14].

Would America wink to India to go to the town? American neutrality will be decisive. The stakes are to the tune of trans- Eurasian security system. The forging of new relationship with China is an imperative. Yet again, the spirit of the architect of Sino-Pak relations and nuclear programme stands vindicated.

Apart from American arming of India, Israelis supplied Indians with the hardware during Kargil. The transformation in the relationship between India and Israel is hailed as a strategic alignment out across the entire region of South Asia and the Greater Middle East [15]. In 1965 war, Tel Aviv provided arms to India without Washington's knowledge. It is covertly helping Indian nuclear programme. What are Pakistan's gains to balance the raising of ties with Israel? 
The relationship with Israel fits only in the context of national interest.

The Indian refusal to concede on Kashmir continues. Whereas in Israeli perception, Pakistan has come a long way but not long enough. What is the set of circumstances that will convey to Israel what its leadership expects? The diplomacy to yield without proceeds is to end. Will ties with Israel create an anti-castration diplomatic space for Pakistan?

A defeat in a war will one-day be forgotten; occupation is a cause of enmity so long as it goes on [16]. Located as a linchpin on the multiple axes of global power struggle, restraint and the passage of time shall guide Pakistan. While the White House encourages India's nuclear power, Israel is pushing Washington to destroy Iran's nuclear plants and Pakistan may be the next target [17].

In September 2005, India voted against Iran and in favor of International Atomic Energy Agency (IAEA) resolution sponsored by Britain, France, Germany (EU-3) and backed by US. Within days of October 8 earthquake, India urged IAEA to act against nuclear proliferators. From global nuclear disarmament to non-proliferation, Indian paradigm shift is clear as a bell. The Indo-US entente speaks for itself.

The actors involved must have taken everything into account. A safe academic assumption is not in the manifestation of what happens on ground but in the perception of the issue. So far as Pakistan is concerned, the Indo-US connection is converging. Pakistan is not catered for on the draughtsmen table. The game played is with a time dimension not in scale with Pakistan. Will America overload the circuitry? Would Pakistan knuckle under global and regional hegemony?

An event can trigger chaos theory. The theory assumes natural order to be so precariously balanced that the flutter of the butterfly wings in Northeast Asia can cause a cyclone in the Bay of Bengal or perhaps an earthquake in the Himalayas. Chaos theory is not based so much on quantum but on differential calculus. It is mathematical.

When the system is closely coupled as the globalized world today is by virtue of information technology, feeble tremors can turn violent. Notwithstanding a nuclear war. The world is at a critical balance. Crash will be global. The most impressive part of the power is its holding back. The great and the most telling is restraint. The peace in South Asia depends on how the situation develops in relation to Kashmir dispute and Baglihar. If there is no progress, the circuitry of relationship will be overloaded. A pre-mature agreement is always tempting, but when it shatters, one is taken aback in strange and different ways. The desire for Nobel peace prize and national interest are two different things.

Sometimes things occur in constellations and difficulties in clusters. The understanding of macro is in the micro and vice versa. Big things occur out of an event and for great reasons. For the same reasons, the passage of time pushes towards an event. It is compulsion of the time to push it towards you. Future happens through an event. Events cast the casting of lots or die e.g., 9/11 or the October 8 earthquake in Pakistan.

Pakistan's post 9/11 night of trial continues. The October 8 earthquake heightens it. The federation of Pakistan is shaken to the core. The earthquake is a decomposition of Pakistan. Metabolism of the entire country is under stress. Metaphorically, it was a massive heart attack. Margalla Towers is its symbol. Pakistani state is badly exposed. It needed cataclysm to shake its roots. The contradictions on all fronts have been amplified. Devolution of power, a contradiction in itself, had to have this calamity to prove its unsoundness. The sublimation is going beyond the threshold and leadership disoriented. His is Vygotskyian agony. Pakistan will never be the same again. For what day the earthquake occurred? The circumstance is Nature [18]. Decomposition is recomposition [19]. The general law is at work and linkage visible. With roots in the language problem, the 1971 crises after all were triggered by a cyclone.

When time becomes space and space becomes time, concrete factors along with intangible time becomes the centre of gravity. Time creates an impact. Bring to witness the passage of time that times change. Allow passage of time as part of perception and calculations. Let the passage of time to alter, adapt, modify, add, amend and heal. For it unveils serendipity. Pakistan shall permit the wings of time to flutter change and preserve its nuclear weapon capability.

I returned and saw under the sun, that the race is not to the swift, nor the battle to the strong, neither yet bread to the wise, nor yet riches to the men of understanding, nor yet favor to men of skill; but time and chance happeneth to them all [20].

The mind seldom rests [21]. It is the faculty of human mind to become what it contemplates [22]. Like dreams, the contemplative consciousness may allow a reworking of mental schemata and enduring attitudes in a unique way [23]. I do not perceive in order to perceive but in order to orient myself, to pave the way in dealing with something [24].

Times change and with it everything changes. Reality passes through us as time, at times as tragedy. Time with ethics is balm as well. Pakistani consciousness will have to rise to the scale of tragedy, as also in the realm of foreign policy to defend its threshold of tolerance. Fate is for imbeciles [25]. It is written on the gate of Heaven, Woe unto him who suffers himself to be betrayed by Fate! [26]. Uncertainty is the fact of life. In Pakistan, it is order of the day and that is the reality. Pakistanis suffer from an inadequacy to state their wisdom and there is something to be said. To begin with, Pakistan needs an empirical astuteness and an inner instinct for justice and liberty of thought. In the absence of effective institutional framework and reformist thinkers, a Centaur is needed. 


\section{REFERENCES}

[1] Evans, Graham. \& Jeffrey Newnhan, Dictionary of International Relations, London: Penguin Group. 1998, p.197.

[2] Cooper, Robert. The Breaking of Nations: Order and Chaos in the Twenty-First century, London: Atlantic Books. 2004, pp.83 \& 63.

[3] Sestanovich, Stephen. 'American Maximalism', in The National Interest, Number 79. Washington, DC. Spring 2005. p.13.

[4] Larrabee, F. Stephen. John Gordon iv \& Peter A. Wilson, 'The Right Stuff: Defense Planning Challenges for A New Century', in The National Interest, Number 77. Washington, DC. Fall 2004, p.54.

[5] Kissinger, Henry A. Quoted in, 'The Indian Imperative: A conversation with Robert D. Blackwill', in The National Interest, Number 80. Washington DC. Summer 2005, p.12.

[6] Shahid M. Amin. 'Indian strategic thinking', Dawn Books \& Authors (Karachi) 20 February 2005, p.10.

[7] Randeep Ramesh. 'The empire shifts', Dawn (Islamabad) 09 April 2005. p.14.

[8] Marvi Memon. 'Reorientation of Pakistan's Foreign Policy after the Cold War', in (ed.). Mehrunnisa Ali, Reading in Pakistan Foreign Policy: 1971-1998. Karachi: Oxford University Press. 2001, p.404.

[9] Travis, Thom A.'Advantages and Disadvantages for Pakistan in the Post-Cold War World' in (ed.). Mehrunnisa Ali, ibid., p.431.

[10] Margolis, Eric S. 'New US-India axis', Dawn (Islamabad) 19 April 2005, p.7.

[11]Dawn. 'Pakistan, China sign treaty of friendship', (Islamabad) 6 April 2005, p.1.

[12] Kissinger, Henry A. 'Cooperation, not Conflict', Dawn (Islamabad) 20 June 2005, p.7.
[13] Cooper, Robert. The Breaking of Nations: Order and Chaos in the Twenty-First Century, London: Atlantic Books. 2004, p.77.

[14] Najmuddin A. Shaikh. 'Indo-US nuclear agreement', Dawn (Islamabad) 10 August 2005, p.7.

[15]Rajan Menon \& Swati Pandey. 'An Axis of Democracy', in The National Interest, Number 80, Washington DC, Summer 2005, p.29.

[16] Cooper, Robert. The Breaking of Nations: Order and Chaos in the Twenty-First Century, London: Atlantic Books. 2004, p. 120.

[17] Margolis, Eric S. 'Missile test accord', Dawn (Islamabad) 16 August 2005, p.7.

[18]Emerson, Ralph Waldo. Fate In The Conduct of Life, Volume vi. Boston: The Riverside Press. 1880, p.20.

[19] Emerson, Ralph Waldo. Plato, or the Philosopher in REPRESENTATIVE MEN, 1850. Rpt; The Belknap Press. London. 1996, p.46.

[20] Strunk, Williams \& E. B. White. The Elements of Style, 1919. Rpt; Longman: New York. 2000, p.23.

[21]Wilber, Ken. Jack Engler \& Daniel P. Brown. Transformations of Consciousness: Conventional and Contemplative Perspectives on Development, New Science Library: Boston. 1986, p.viii.

[22] Paine, Thomas. Rights of Man, 1790. Rpt. Penguin Classics: New York. 1985, p.109.

[23] Wilber, Ken. Jack Engler \& Daniel P.Brown. loc.cit. p.ix.

[24]Heidegger, Martin. History of the Concept of Time, Trans. from German. Theodore Kisiel. 1925. Bloomington: Indiana University Press. 1985, p.30.

[25] Emerson, Ralph Waldo. Montaigne, or the Skeptic in REPRESENTATIVE MEN, 1850. Rpt; The Belknap Press. London. 1996, p.99.

[26]FATE in The Conduct of Life, Volume VI. Boston: The Riverside Press. 1880, p.33. 